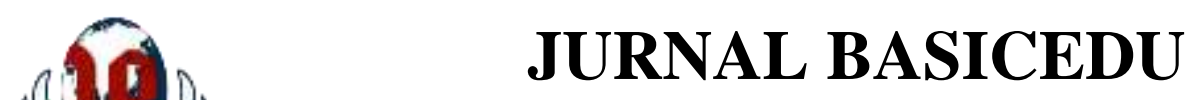

Volume 5 Nomor 5 Tahun 2021 Halaman 4127 - 4137

Research \& Learning in Elementary Education

https://jbasic.org/index.php/basicedu

\title{
Implementasi Nilai-nilai Pancasila dalam Food and Beverage Departemen di Restoran Hotel New Saphir Yogyakarta
}

\author{
Heri Kurnia $^{1 凶}$, Ida Ayu Sriyogani ${ }^{2}$, Nuryati ${ }^{3}$ \\ Pendidikan Pancasila dan Kewarganegaraan, Universitas Cokroaminoto Yogyakarta, Indonesia ${ }^{1,2,3}$ \\ E-mail: herikurnia312@gmail.com ${ }^{1}$, idaayusriyogani@gmail.com² ${ }^{2}$, nuryatikip@ gmail.com ${ }^{3}$
}

\begin{abstract}
Abstrak
Penerapan nilai-nilai Pancasila di lingkungan masyarakat telah terjadi sebelum pengesahan Pancasila sebagai dasar dan pedoman hidup masayarakat Indonesia dan sampai saat ini masih tetap diterapkan, begitu juga dengan bidang-bidang seperti pariwisata, pemerintahan, sosial dan masih banyak lagi. Dalam dunia pariwisata khususnya akomodasi perhotelan terdapat nilai-nilai Pancasila yang dikemas menjadi SOP (Standar Operasional Prosedur) sehigga karyawan lebih mudah untuk menerapkan di lingkungan kerja. Tujuan penelitian ini adalah 1. Mengetahui penerapan nilai-nilai Pancasila di Restoran Hotel New Saphir Yogyakarta 2. Faktor-faktor penghambat dan juga pendukungnya. Penelitian ini menggunakan metode deskriptif kualitatif. Adapun teknik analisis data menggunakan teori Miles dan Hubberman beserta data primer dan sekunder, tegasnya menggunakan teknik wawancara dan juga data lain yang mendukung penelitian seperti informasi dari internet. Hasil dari pada penelitian antara lain: 1. Karyawan Hotel New Saphir Yogyakarta terkhusus departemen food and beverage telah melaksanakan dan juga menerapkan nilai-nilai pancasila 2. SOP ini berlaku bagi karyawan dan tidak dapat dilanggar 3. Faktor pendukung terlaksananya nilai-nilai pancasila adalah yang paling utama kekompakan 4. Faktor penghambatnya adalah rasa ego yang tinggi hanya untuk kepentingan serta kepuasan pribadi. Kesimpulannya ialah bahwa kita sebagai bangsa Indonesia harus taat aturan baik yang berbentuk lisan maupun tulisan, begitu juga dengan para karyawan perusahaan yang diharuskan taat terhadap SOP yang berlaku guna meminimalisir kesalahan yang mungkin akan terjadi. Dari hasil penelitian di Hotel New Saphir Yogyakarta dengan 3 narasumber dihasilkan informasi bahwasanya di Hotel tersebut telah menerapkan nilai-nilai Pancasila yang berlaku di perhotelan.
\end{abstract}

Kata Kunci: Implementasi nilai-nilai Pancasila, departemen food and beverage, Hotel New Saphir.

\begin{abstract}
The application of Pancasila values in the community has occurred before the ratification of Pancasila as the basis and guideline of indonesian society and until now is still applied, as well as fields such as tourism, government, social and many more. In the world of tourism, especially hospitality accommodation, there are Pancasila values that are packaged into SOPs (Standard Operating Procedures) so that employees are easier to implement in the work environment. The purpose of this study is 1. Know the application of Pancasila values at Hotel New Saphir Yogyakarta Restaurant 2. Inhibitory factors as well as their supporters. This research uses qualitative descriptive methods. Data analysis techniques using Miles and Hubberman theory along with primary and secondarydata, it is firmly using interview techniques and also other data that support research such as information from the internet. The results of the study include: 1. Employees of Hotel New Saphir Yogyakarta especially the food and beverage department have implemented and also applied the values of Pancasila 2. This SOP applies to employees and cannot be violated 3. The supporting factor of the implementation of pancasila values is the main cohesiveness 4. The inhibiting factor is a high sense of ego only for personal interests and satisfaction. The conclusion is that we as an Indonesian nation must obey the rules both in oral and written form, as well as the employees of the company who are required to obey the applicable SOP to minimize mistakes that may occur. From the results of research at Hotel New Saphir Yogyakarta with 3 sources generated information that the hotel has applied pancasila values that apply in hospitality.
\end{abstract}

Keywords: Implementation of Pancasila values, food and beveragedepartment, Hotel New Saphir

Copyright (c) 2021 Heri Kurnia, Ida Ayu Sriyogani, Nuryati

Corresponding author :

Email : herikurnia312@gmail.com

DOI $\quad$ : https://doi.org/10.31004/basicedu.v5i5.1473

ISSN 2580-3735 (Media Cetak)

ISSN 2580-1147 (Media Online) 
4128 Implementasi Nilai-Nilai Pancasila dalam Food And Beverage Departemen di Restoran Hotel New Saphir Yogyakarta - Heri Kurnia, Ida Ayu Sriyogani, Nuryati

DOI: https://doi.org/10.31004/basicedu.v5i5.1473

\section{PENDAHULUAN}

Pariwisata berasal dari bahasa sanksakerta yang merupakan gabungan dari dari dua kata yaitu pari dan wisata (Arliman, 2018). Pari artinya bekali-kali, berulang-ulang, berkeliling dari satu tempat ke tempat yang lain. Wisata adalah perjalanan dari suatu tempat ke tempat lain (Hanief et al., 2018). Pariwisata ialah segala sesuatu yang berhubungan dengan perjalanan wisata ke tempat objek pariwisata (Ahmad \& Sigarete, 2018). Pariwisata adalah salah satu kebutuhan hidup manusia untuk menghilangkan rasa lelah, dan melepaskan penat sejenak dari aktivitas bekerja (Hidayah, 2019). Dalam Undang-undang No. 10 tahun 1990 dinyatakan bahwa pariwisata adalah segala sesuatu yang berhubungan dengan wisata termasuk pengusahaan objek dan daya tarik wisata serta usaha-usaha yang terkait dibidang tersebu (Kepariwisataan, 2009).

Dalam Jurnal penelitian yang berjudul "Motivasi wisatawan mengunjungi objek wisata di Desa Pawan Kabupaten Rokan Hulu", pengertian pariwisata menurut N. R. Harsono dan F. Yusrizal, (2013) pariwisata adalah perpindahan sementara yang dilakukan manusia dengan tujuan keluar dari pekerjaan-pekerjaan rutin, keluar dari tempat kediamannya. Aktivitas yang dilakukan selama mereka tinggal di tempat yang dituju dan fasilitas dibuat untuk memenuhi kebutuhan mereka (Pradana, 2019).

UU No. 10 tahun 2009 "Kepariwisataan" keadaan alam, flora, dan fauna sebagai karunia Tuhan Yang Maha Esa, serta peninggalan purbakala, peninggalan sejarah, seni dan budaya yang dimiliki bangsa Indonesia merupakan sumber daya dan modal pembangunan kepariwisataan untuk peningkatan kemakmuran dan kesejahteraan rakyat (Kepariwisataan, 2009). Menurut Nasrullah et al., (2020) wisata minat khusus adalah suatu perjalanan wisata yang dilakukan atas dasar minat dan motivasi khusus wisatawan untuk melakukan kunjungan dan terlibat dalam suatu kegiatan wisata yang spesifik dengan menekankan unsur kegiatan yang unik dan pengalaman yang berkualitas. Dengan adanya destinasi wisata di berbagai daerah ini menjadikan pembuka dan pemekaran perekonomian bagi warga setempat untuk meningkatkan perekonomian dengan memasarkan produk-produk khas daerah, pakaian adat, alat-alat musik tradisional dan kuliner tradisional maupun kuliner pada umumnya (Revida et al., 2020).

Suguhan pariwisata yang berbagai macam termasuk kuliner menjadi daya tarik wisatawan tersendiri, kuliner makanan tradisional yang dijajakan di wilayah destinasi wisata bertujuan untuk memperkenalkan makanan tradisional setempat (Rusyidi \& Fedryansah, 2018). Bangsa Indonesia terdiri dari berbagai macam suku, budaya, ras, agama, adat istiadat, dengan keberagaman ini bangsa Indonesia menghasilkan dan memiliki makanan tradisional khas daerah dengan karakter dan keunikan masing-masing daerahnya. Kuliner tradisional ini adalah warisan yang diberikan secara turun temurun dan menjadi kekayaan yang tak ternilai harganya (Ridwan \& Aini, 2019).

Zaman yang semakin berkembang dan maju ini, menjadi tantangan utama bagi pelaku ekonomi terutama penjual makanan tradisional mengenai bagaimana mempertahankan cita rasa, bentuk, dan ciri khas agar tidak tertinggal zaman ataupun terbaur dengan makanan internasional atau menyajikan makanan tradisional dengan gaya modern yang lebih menarik minat pembeli tetapi tidak menghapus cita rasa dan ciri khas makanan tersebut (Yuningsih et al., 2019). Fase perkembangan kuliner Indonesia dibagi menjadi tiga antara lain: fase pertama atau biasanya disebut fase original food, fase ini ada di zaman dahulu yaitu di zaman kerajaan besar nusantara sebelum kedatangan penjajah. Ciri makanan ini yaitu dikukus, dibungkus daun pisang dan bahan baku utamanya adalah beras dan umbi-umbian. Fase kedua atau biasanya disebut multiculture food, kuliner dimasa ini telah dipadukan atau dipengaruhi oleh seni memasak para pendatang seperti pendatang dari negara Belanda, China dan Arab. Fase ketiga adalah kuliner kontemporer yang banyak dipengaruhi oleh kuliner eropa, dimana kuliner ini mengarah pada makanan instant (fast food). Menurut Nuralam \& Sulistyani, (2017) kualitas kuliner baik tradisonal maupun internasional tidak lepas dari peran para koki dan pelayan. Koki dan pelayan dibidang pariwisata disebut sebagai $F \& B$ service dan $F \& B$ product. 
4129 Implementasi Nilai-Nilai Pancasila dalam Food And Beverage Departemen di Restoran Hotel New Saphir Yogyakarta - Heri Kurnia, Ida Ayu Sriyogani, Nuryati

DOI: https://doi.org/10.31004/basicedu.v5i5.1473

Food and beverage $(F \& B)$ merupakan salah satu bidang yang vital dan sangat penting dalam industri pariwisata, tanpa bidang ini para tamu akan kesulitan dalam memenuhi kebutuhan makan dan minumnya (PUTRANTO, 2017). Food and beverage dibagi menjadi dua jenis yaitu food \& beverage service dan food \& beverage product, dimana fungsi dari pada food \& beverage sevice adalah suatu bagian yang bertugas dan bertanggungjawab terhadap pelayanan makanan dan minuman bagi para tamu (SUGIARNO, 2017). Jurnal Khasanah Ilmu dengan judul upaya food and beverage restaurant dalam meningkatkan kepuasan tamu melalui variasi product mengemukakan penjelasan mengenai $F \& B$ service. Menurut Yusnita \& Yulianto, (2013) food and beverage service di dalam sebuah hotel mempunyai beberapa seksi diantaranya yaitu: main dining room, coffee shop, soda fountain dan lain-lain. Food and beverage service atau lebih dikenal dengan sebutan waiterss mempunyai tugas untuk melayani tamu yang datang, menyapa pelanggan, menggiring tamu ke kursi yang telah di pesan maupun kursi yang belum di tempati, memberikan buku menu dan juga bagi waiterss dituntut untuk ramah dan sopan terhadap tamu yang datang, memberikan pelayanan yang memuaskan agar tamu merasa puas (Sasaka, 2019). Sedangkan menurut Kurniawan \& Sidiq, (2016) food \& beverage product adalah suatu bagian yang bertugas dan bertanggungjawab terhadap penyediaan (production) makanan dan minuman untuk para tamu.

Jurnal Khasanah Ilmu mengemukakan pendapat Wulansari \& Hakim, (2019) pengertian product yang dihasilkan organisasi food and beverage adalah totalitas dari makanan dan minuman beserta seperangkat atribut lainnya, termasuk di dalamnya ada rasa, warna, aroma makanan, harga dan lain-lain. Dalam (Holidah, n.d.) Food and beverage product yang biasanya disebut kitchen mempunyai beberapa seksi yaitu: main kitchen, pastry, butcher, saucier, potagier dan lain-lain. Food and beverage product bertugas untuk membuat makanan baik sesuai pesanan tamu yang telah disediakan di buku menu atau prasmanan bagi tamu yang mempunyai acara wedding, birthday party dan lain-lain, dan juga menu untuk acara table manner dimana menu yang disajikan berurutan mulai dari appetizer, soup, main course, dan dissert (Nuralam \& Sulistyani, 2017). Selain bertugas untuk membuat makanan $F \& B$ product juga harus membuat sajian atau garnish yang bisa memikat tamu untuk berkunjung dan mencicipi makanan (Holidah, n.d.). Setiap bidang baik $F \& B$ product maupun $F \& B$ service pastinya mempunyai SOP (Standar Operating Prosedure) dimana isi dari pada SOP ini adalah etika dalam pelayanan makanan dan minuman, etika dalam berpakaian, kerapian diri sendiri, aturan berbicara yang baik dan benar dan masih banyak lagi.

SOP (Standar Operating Prosedure) yaitu suatu panduan yang menjelaskan tentang bagian suatu proses kegiatan harus dilaksanakan untuk mencapai manfaat maksimal dengan resiko seminimal mungkin. Pendapat lain mengatakan bahwa SOP adalah pedoman atau acuan untuk melaksanakan tugas dan pekerjaan sesuai dengan fungsi dari pekerjaan tersebut. Dalam jurnal "Analisis Implementasi Standard Operation Prosedure (SOP) dalam menjaga kualitas layanan teller" mengemukakan pendapat Tathagati (2014) SOP dapat didefinisikan sebagai dokumen yang menjabarkan aktivitas operasional yang dilakukan sehari-hari, dengan tujuan agar pekerjaan tersebut dilakukan secara benar, tepat dan konsisten. Untuk menghasilkan produk yang sesuai dengan standar yang telah ditetapkan sebelumnya. Dengan adanya SOP perusahaan akan lebih mudah mengontrol pegawai perusahaan dan lebih mudah menata operasional perusahaan supaya tujuan perusahaan yang telah di rancang dapat tercapai dan memenuhi standar.

Jurnal peneltian tesis dengan judul "Analisis Penerapan Standart Operating Procedure (SOP), Organization Citizenship Behavior (OCB), dan kompetensi kerja terhadap produktivitas dan kinerja karyawan politeknik pelayanan Surabaya" mengemukakan pendapat Santoso (2014: p 10-14) SOP terdiri dari 7 hal pokok yaitu efisisensi, konsisten, minimalisasi kesalahan, penyelesaian masalah, perlindungan tenaga kerja, peta kerja dan batasan pertahanan.

Dengan adanya SOP di harapkan dapat memenuhi prosedur yang telah di tetapkan oleh pemerintah baik pusat maupun daerah guna melancarkan kegiatan usaha, dan dengan adanya SOP ini diharapkan tidak ada penyimpangan di luar hukum khususnya nilai-nilai Pancasila (Antari \& Liska, 2020). Menurut Asmaroini, 
4130 Implementasi Nilai-Nilai Pancasila dalam Food And Beverage Departemen di Restoran Hotel New Saphir Yogyakarta - Heri Kurnia, Ida Ayu Sriyogani, Nuryati

DOI: https://doi.org/10.31004/basicedu.v5i5.1473

(2016) nilai-nilai Pancasila yang dimaksudkan adalah mengenai anjuran dan larangan yang harus dipatuhi. Nilai-nilai Pancasila terdapat 5 sila, yaitu yang pertama: Ketuhanan Yang Maha Esa, kedua: Kemanusiaan yang adil dan beradab, ketiga: Persatuan Indonesia, keempat: Kerakyatan yang dipimpin oleh hikmat kebijaksanaan dalam permusyawaratan/perwakilan, dan yang kelima: Keadilan sosial bagi seluruh rakyat Indonesia. Dari kelima sila tersebut dapat dipadukan dengan SOP perhotelan terkhusus pada bidang food and beverage, dimana $F \& B$ ini berperan penting dalam pengolahan sampai pelayanan makanan bagi tamu yang datag berkunjung (Damanhuri et al., 2016). Dapat peneliti jelaskan hubungan nilai-nilai Pancasila dengan food and beverage sebagai berikut: sila pertama "Ketuhanan Yang Maha Esa, dimana sila ini mengarah pada jenis makanan halal dan non halah, disinilah pihak pengelola restoran harus bertindak tegas mengenai bahan makanan halal dan non halal menginggat di negara Indonesia terdapat beragam agama yang dipercaya dan dianut masyarakat sehingga terdapat banyak ajaran dan pantangan yang berbeda-beda terutama pada kelayakan makanan dan minuman yang dikonsumsi", sila kedua "Kemanusiaan yang adil dan beradab, dimana sila ini mengarah pada sama rata antar masyarakat, perbedaan ras, agama, suku dan budaya bangsa Indonesia, disini pegawai restoran harus di berikan pengertian/ wejangan supaya bersikap adil terhadap tamu", sila ketiga "Persatuan Indonesia, dalam suatu perkumpulan kerja pastinya banyak perbedaan baik pendapat maupun secara pemikiran, sikap inilah yang harus di tindak tegas supaya tidak terjadi perselisihan antar pegawai maupun pengunjung restoran", sila keempat "kerakyatan yang dipimpin oleh hikmat kebijaksanaan dalam permusyawaratan/ perwakilan, disinilah peran atasan yang perlu dipahami, seorang atasan hendaknya bersikap adil dan menciptakan keharmonisan di lingkungan kerja selain itu seorang atasan harus mempunyai rasa tanggungjawab yang tinggi terhadap pegawai", sila kelima "Keadilan sosial bagi seluruh rakyat Indonesia, dimana sila ini menegaskan bahwa keadilan yang di dapatkan semua orang harus sama rata tanpa pandang ras, agama, adat dan budaya, supaya tercipta kehidupan yang harmonis antar sesama".

\section{METODE}

Penelitian ini bertempat di Hotel New Saphir Yogyakarta yang beralamat di Jalan Laksda Adisucipto No. 38, Yogyakarta. Hotel New Saphir merupakan salah satu Hotel di Yogyakarta yang menerapkan nilainilai Pancasila dalam Food and Beverage (Hutahean, 2016). Pelaksanaan penelitian menghabiskan waktu selama satu bulan mulai dari Mei 2021 sampai dengan Juni 2021. Metode yang digunakan dalam penelitian ini yaitu penelitian deskriptif kualitatif (Moleong, 2009). Menurut Sugiyono, (2014) metode penelitian kulitatif adalah metode penelitian yang berdasarkan pada filsafat post positivisme, yang digunakan untuk meneliti pada kondisi objek yang alamiah, dimana peneliti adalah sebagai instrumen kunci, pengambilan sampel sumber data dilakukan secara purposive dan snowball, teknik pengumpulan dengan tri anggulasi/ gabungan, analisi data bersifat induktif atau kualitatif, dan hasil penelitian kualitatif lebih menentukan makna dari pada generasi. Menurut Bogdan dan Tylor dalam Lexi, (2005) mengemukakan bahwa penelitian kualitatif adalah prosedur penelitian yang menghasilkan data deskriptif berupa kata-kata tertulis atau lisan dari orang-orang dan perilaku yang dapat diamati. Subjek penelitian ialah pihak yang akan membantu dalam proses penelitian dan penggalian data (Moleong, 2010). Selanjutnya dalam Lexi, (2001) subjek peneltian atau pihak-pihak yang dijadikan sebuah sampel dalam sebuah penelitian. Subjek penelitian juga membahas karakteristik subjek yang digunakan dalam penelitian, termasuk penjelasan mengenai populasi, sampel, dan teknik sampling (acak/ non acak) yang digunakan (Moleong, 2002). Adapun subjek dari penelitian ini adalah karyawan departemen food and beverage product dan food and beverage service Hotel New Saphir Yogyakarta yang berjumlah 3 (tiga) orang yang terdiri dari dua orang Staff food and beverage dan satu orang Staff Maintenance and Technic. 
4131 Implementasi Nilai-Nilai Pancasila dalam Food And Beverage Departemen di Restoran Hotel New Saphir Yogyakarta - Heri Kurnia, Ida Ayu Sriyogani, Nuryati

DOI: https://doi.org/10.31004/basicedu.v5i5.1473

\section{HASIL DAN PEMBAHASAN}

Menerapkan nilai-nilai Pancasila $F \& B$ sama halnya seperti attitude pada kehidupan sehari-hari. Contohnya seperti sapa, sopan, santun dan senyum yang biasanya menjadi dasar dalam bersosial antar masyarakat baik itu di dalam lingkungan keluarga maupun di lingkungan masyarakat, sama halnya dengan penerapan nilai-nilai Pancasila di lingkungan Hotel New Saphir Yogyakarta dimana para karyawan telah terbiasa dengan kehidupan yang berdasar pada nilai-nilai Pancasila apa lagi di wilayah Yogyakarta sendiri mempunyai aturan adat dimana masyarakatnya wajib menerapkan unggah-ungguh baik dalam bertata krama maupun bertata bahasa baik dengan orang yang lebih tua, setara maupun anak-anak dibawah umur. Hal inilah yang menjadi faktor pendukung untuk lebih menjunjung tatanan kehidupan masyarakat baik pendatang ataupun masyarakat asli untuk selalu menerapkan tata krama yang baik supaya tujuan dari pada keharmonisan antar masyarakat dapat terealisasikan.

Karyawan Hotel New Saphir Yogyakarta adalah karyawan yang selalu mematuhi aturan baik aturan yang telah dibuat tulisan di lingkungan Hotel yang biasanya berupa SOP (Standar Operasional Prosedur) mapun aturan yang memang berasal dari adat DIY (Daerah Istimewa Yogyakarta) yang diterapkan secara turun temurun dari zaman terdahulu hingga sekarang. SOP ini mencangkup nilai-nilai Pancasila mulai dari sila pertama hingga sila kelima, sehingga dalam menjalankan tugas sebagai karyawan Hotel tidak akan menyalahi aturan baik aturan yang telah diterbitkan perusahaan maupun peraturan yang disahkan negara.

\section{Deskripsi tentang penerapan nilai-nilai Pancasila di departemen food and beverage service.}

Penerapan nilai-nilai Pancasila dalam departemen food and beverage di restoran Hotel New Saphir Yogyakarta telah diterapkan bagi karyawan yang bekerja di departemen tersebut. Isi dari padaSOP antara lain nama barang-barang seperti plate, fork, spoon, knife, bowl, glass, napkin dan masih banyak lagi, berisi juga mengenai tata aturan berkomunikasi dengan tamu, tata busana, hygene sanitasi dan lain-lain. Penerapan nilainilai Pancasila juga telah dijelaskan oleh bapak Isma Wahyu Utama selaku Staff Maintenance and Technic Hotel New Saphir mengatakan bahwa:

"Sila pertama: Iya, $F \& B$ restoran dalam melaksanakan produk maupun pelayanan telah menerapkan nilai-nilai Pancasila, khususnya nilai Ketuhanan Yang Maha Esa, yang intinya adalah kita percaya adanya Tuhan selain itu juga saling menghormati antar agama. $F \& B$ sangat memperhatikan makanan dan minuman yang menjadi larangan bagi masing-masing agama, misalkan bagi yang beragama islam (adanya halal dan haram), daging babi adalah haram, maka dalam memproduksi dilakukan pemisahan secara khusus untuk produk-produk makanan yang diharamkan oleh agama islam, termasuk yang dilarang untuk dikonsumsi oleh agama-agama yang lain. Sebagaimana kita ketahui di Indonesia mengakui enam agama, yakni: Islam. Kristen, Katholik, Hindu, Budha dan Konghucu" (Yogyakarta, 25 Mei 2021).

Pada sila pertama ini dijelaskan bahwa Ketuhanan Yang Maha Esa bersangkutan dengan kepercayaan yang dianut masyarakat Indonesia bahwa setiap agama yang dianut memiliki aturannya masing-masing seperti di agama islam yang mengharamkan babi untuk dikonsumsi, maka disetiap rumah makan di Indonesia memiliki keterangan untuk makanan halal dan non halal, selain itu setiap agama di Indonesia juga memiliki aturan dalam beribadah seperti dalam islam sholat 5 waktu.

"Sila kedua: Ya, $F \& B$, restoran dalam melaksanakan produk maupun pelayanan telah menerapkan nilainilai Pancasila, khususnya nilai-nilai Pancasila sila kedua yaitu kemanusiaan yang adil dan beradab. Dalam memproduksi dan memberikan pelayanan pada customer departemen $F \& B$ selalu mengikuti SOP yang telah ditetapkan perusahaan, tidak membedakan antara customer satu dengan yang lain, namun memperhatikan permintaan customer. Dengan telah melaksanakan tugas produk maupun pelayanan sesuai dengan SOP berarti telah melaksanakan nilai-nilai Pancasila, Karena SOP telah disusun dengan berlandaskan pada nilai-nilai Pancasila" (Yogyakarta, 25 Mei 202). 
4132 Implementasi Nilai-Nilai Pancasila dalam Food And Beverage Departemen di Restoran Hotel New Saphir Yogyakarta - Heri Kurnia, Ida Ayu Sriyogani, Nuryati

DOI: https://doi.org/10.31004/basicedu.v5i5.1473

Pada sila kedua ini dijelaskan bahwa baik pelayanan maupun produk telah melaksanakan tugas dan kewajiban sesuai dengan SOP yang berlaku di departemen terkait yaitu memuaskan customer baik dengan pelayanan yang maksimal dan juga makanan yang sesuai dengan pesanan.

"Sila ketiga: Ya. $F \& B$, restoran dalam melaksanakan produk maupun pelayanan telah menerapkan nilai-nilai Pancasila, khususnya persatuan Indonesia. Menghargai sesama karyawan baik dalam lingkungan $F \& B$ termasuk manajemen diluar $F \& B$ adalah suatu keharusan, kerjasama dalam satu tim yang kuat merupakan keharusan, karena dengan kerja tim yang baik akan dihasilkan produk dan pelayanan yang baik pula" (Yogyakarta, 25 Mei 2021).

Pada sila ketiga ini menjelaskan bahwa para karyawan sangat menghargai sesama baik karyawan product maupun service, dengan kesadaran tinggi dalam bersosial para karyawan tidak sungkan dalam membantu sesama, sebab dalam kekompakan para tim ini akan menghasilkan kesuksesan dalam bekerja.

"Sila keempat: Ya. $F \& B$, restoran dalam melaksanakan produk maupun pelayanan telah menerapkan nilai-nilai Pancasila, khususnya kerakyatan yang dipimpin oleh hikmat kebijaksanaan dalam permusyawaratan/ perwakilan. Sebelum melaksanakan tugas, selalu diadakan briefing sehingga diharapkan akan dapat bekerja nyaman, dan jika ada permasalahan dalam pelaksanaan tugas produk maupun pelayanan diselesaikan dengan cara musyawarah untuk mufakat, akan terjadi saling memperkuat antar tim satu dengan yang lain" (Yogyakarta, 25 Mei 2021).

Pada sila keempat ini dijelaskan bahwa sebelum memulai pekerjaan biasanya diadakan briefing bagi karyawan untuk mengarahkan dan tentunya berdoa meminta keselamatan kepada Allah Tuhan Yang Maha Esa, dan juga manfaat dari briefing tersebut adalah memperkuat tim dalam melakukan pekerjaan, menjaga kekompakan dan juga jika terjadi permasalahan dapat diselesaikan secara musyawarah.

"Sila kelima: Ya. $F \& B$, restoran dalam melaksanakan produk maupun pelayanan telah menerapkan nilai-nilai Pancasila, khususnya keadilan bagi seluruh rakyat Indonesia. Kebersamaan keadilan bersama merupakan tujuan bersama, bagi yang yang terlemah akan mendapat perhatian khusus, yang kuat dengan kesadaran penuh pasti membantu yang lemah, misalnya bagian produk mengalami kesulitan yang kuat akan membantu, dalam pembagian rejeki keadilan sangat diperhatikan sekali, bagi yang mendapatkan paling kecil akan dibantu oleh yang kuat dengan kesadaran suka rela yang sangat tinggi, saling tolong menolong, kesetaraan antar pegawai yang sangat tinggi sekali, persaudaraan dibangun dengan sangat baik, apalagi di masa pandemic seperti sekarang ini, terpaksa ada pengurangan pegawai dan lain sebagainya, pegawai yang kuat dengan kesadaran tinggi membantu dengan dasar pesaudaraan yang sudah terjalin dengan baik". (Yogyakarta, 25 Mei 2021).

Pada sila kelima dijelaskan bahwa karyawan selalu mempunyai motivasi diri dalam bekerja guna meningkatkan baik kemampuan maupun pengalaman. Selain itu, para karyawan juga mempunyai rasa persaudaraan yang tinggi terhadap sesama karyawan, sehingga jika terdapat karyawan yang mengalami kesulitan makan mereka akan siap membantu. Tetapi dikatakan pula dampak dari pada pandemi Covid-19 ini, mempunyai pengaruh sangat besar baik pariwisata dan juga perhotelan yang memaksakan pihak Hotel melakukan pengurangan tenaga kerja disebabkan tidak adanya pengunjung karena diberlakukannya PSBB selama pandemi.

Penerapan nilai-nilai Pancasila juga telah dijelaskan oleh Bapak Zaki selaku staff kitchen Hotel New Saphir mengatakan bahwa:

"Di departemen $F \& B$ product karyawan diharuskan bekerja sesuai dengan SOP yang berlakun guna mengurangi atau meminimalisir kesalahan pada saat bekerja. SOP departemen ini, tentunya berdasarkan dengan nilai-nilai Pancasila dan telah disesuaikan dengan tanggungjawab karyawan departemen $F \& B$ product" (Yogyakarta, 25 Mei 2021). 
4133 Implementasi Nilai-Nilai Pancasila dalam Food And Beverage Departemen di Restoran Hotel New Saphir Yogyakarta - Heri Kurnia, Ida Ayu Sriyogani, Nuryati

DOI: https://doi.org/10.31004/basicedu.v5i5.1473

\section{Deskripsi wawancara nilai-nilai Pancasila di departemen food and beverage product.}

Departemen food and beverage product, merupakan tempat dimana bahan makanan mentah diolah menjadi bahan makanan matang, pembuatan saus, fresh fruit dan lain-lain. Di departemen ini akan dibagi menjadi beberapa tempat sesuai fungsi seperti di hot kitchen ialah tempat memasak makanan oriental ataupun kontinental, cold kitchen ialah tempat pembuatan makanan seperti salad, asinan dan lain sebagainya, pastry \& bakery ialah tempat pembuatan roti, cake dan berbagai olahan dissert, butcher ialah tempat penyimpanan daging dan juga pengolahan daging mentah. Dalam menjalankan kewajiban product tidak terlepas dari aturan hukum, biasanya aturan-aturan ini di kemas ke dalam SOP (standar operasional prosedur).

SOP product biasanya berisi tentang tata aturan dalam bekerja, tata busana, macam-macam peralatan masak, sanitasi hygene dan masih banyak lagi. Penerapan nilai-nilai Pancasila di departemen $F \& B$ product dijelaskan pula oleh Bapak Heri Kristanto, selaku staff departemen $F \& B$, bahwa di departemen $F \& B$ product telah menerapkan nilai-nilai Pancasila. Berikut adalah hasil wawancara dengan bapak Heri Kristanto selaku staff departemen $F \& B$ sebagai beriku:

Jawaban dari pertanyaan 1

"Dalam mengolah bahan mkanan halal dan non halal kami akan memisahkan bahan makanan non halal supaya tidak tercampur dengan bahan makanan lainnya. Dan juga memasak bahan makanan halal terlebih dahulu baru memasak bahan makanan non halal, jika kondisi mendesak maka peralatan masak harus di cuci bersih setelah megolah bahan makanan non halal" (Yogyakarta, 25 Mei 2021).

Jawaban dari pertanyaan 2

"Tentunya kami bekerja sesuai dengan aturan SOP yang berlaku karena jika tidak sesuai dengan SOP maka akan terjadi banyak kesalahan yang tidak diinginkan" (Yogyakarta, 25 Mei 2021).

Jawaban dari pertanyaan 3

"Dengan pengarahan yang ketat diawal seblum memulai pekerjaan serta motivasi dan memberikan semangat kepada para team adalah kunci utama agar tidak terjadi kesalah pahaman antar team" (Yogyakarta, 25 Mei 2021).

Deskripsi tentang Faktor Penghambat dan Pendukung pada saat melaksanakan implementasi nilainilai Pancasila pada food and beverage departemen di restoran Hotel New Saphir Yogyakarta.

Di dunia perhotelan pastinya banyak plus dan minusnya tergantung dari keadaan yang sedang dihadapi baik dari perusahaan maupun wilayah, seperti yang sedang kita hadapi saat ini sangatlah membuat rugi banyak pihak tidak hanya di perhotelan saja tetapi di sektor pariwisata, pendidikan dan bisnis-bisnis lainnya. Hal ini sama seperti yang dirasakan oleh Hotel New Saphir Yogyakarta dimana pihak Hotel melakukan pengurangan karyawan guna tetap menstabilkan Hotel supaya tidak terjadi kerugian besar bahkan kebangkrutan. Kebijakan ini juga tidak hanya dilakukan di Hotel ini saja tetapi masih banyak Hotel-hotel lainnya bahkan Hotel bintang 5 (lima) sekalipun.

Mempertahankan kestabilan Hotel tidaklah mudah banyak sekali tantangan yang pasti akan dihadapi, dengan ini fungsi nilai-nilai Pancasila sangatlah berperan penting bagi keberlangsungan perusahaan dan juga menjadi pondasi bagi perusahaan supaya tidak terjadi kolaps, berikut adalah faktor-faktor baik pendukung dan penghambat dalam menerapkan nilai-nilai Pancasila.

1) Faktor pendukung penerapan nilai-nilai Pancasila

a) Kesadaran para karyawan terhadap pentingnya bersosial.

b) Kesadaran para karyawan terhadap pentingnya berdo'a sebelum bekerja dan juga rajin beribadah.

c) Kekompakan team untuk tujuan memajukan dan merealisasikan visi misi Hotel.

d) Sadar akan tanggungjawab yang harus dijalankan

e) Menerapkan sapa, senyum, salam, sopan dan santun

f) Kesadaran dalam menghargai antar sesama. 
4134 Implementasi Nilai-Nilai Pancasila dalam Food And Beverage Departemen di Restoran Hotel New Saphir Yogyakarta - Heri Kurnia, Ida Ayu Sriyogani, Nuryati

DOI: https://doi.org/10.31004/basicedu.v5i5.1473

2) Faktor penghambat penerapan nilai-nilai Pancasila

a) Belum bisa menguasai diri pada saat terjadi permasalahan baik dengan sesama karyawan maupun dengan tamu.

b) Biasanya karyawan yang senior akan lebih dominan.

c) Banyak pihak luar yang mencoba untuk memecah belah persatuan team.

Berdasarkan hasil wawancara yang dilakukan peneliti, maka dapat diketahui bahwa pada tahap implementasi pelayan departemen $F \& B$ di Restoran Hotel New Saphir Yogyakarta, hampir semua karyawan Hotel khususnya departemen food and beverage telah menerapkan nilai-nilai Pancasila baik dalam pelayanan maupun produksi bahan makanan sebagaimana nilai-nilai Pancasila yang dikemas dalam SOP.

\section{Menerapkan nilai-nilai Pancasila yang dikemas dalam SOP (standar operasional prosedur).}

Pada dasarnya setiap kegiatan manusia mengandung nilai-nilai Pancasila seperti beribadah, bersosialisasi, gotong royong, bertransaksi dan berkomunikasi antar sesama manusia, tetapi kita terkadang tidak sadar dengan hal itu, yang berakibat pada melencengnya pengetahuan yang diakibatkan pada masuknya budaya dan pengetahuan asing, maka sangat penting bagi masyarakat Indonesia untuk mengemban pendidikan guna memberi ilmu pengetahuan agar dapat memilah mana pengetahuan yang baik dan tidak baik untuk dilakukan. Sama halnya dengan di dunia perhotelan dimana pada saat berada dibangku sekolah pariwisata kita akan diperkenalkan dengan nilai-nilai Pancasila dala perhotelan yang dikemas dalam bentuk SOP (standar operasional prosedure).

SOP adalah serangkaian aturan yang harus dipatuhi guna menghindari hal-hal yang tidak diinginkan pada saat melaksanakan tugas di tempat kerja. SOP ini, biasanya berisi tata aturan berkomunikasi, berbusana, aturan dalam pelayanan, pembuatan bahan makanan, alat-alat yang digunakan, sanitasi hygene perhotelan dan masih banyak lagi. Sama halnya dengan di Hotel New Saphir Yogyakarta dimana setiap departemen mempunyai SOP masing-masing terkhusus di departemen $F \& B$.

Dalam wawancara, peneliti menanyakan bagaimana penerapan nilai-nilai Pancasila di Hotel dan juga departemen $F \& B$, narasumber sangat antusias pada saat memberi penjelasan mengenai pertanyaan yang diajukan peneliti, sebab pertanyaan wawancara ini sangatlah penting bagi keberlangsungan Hotel dan karyawan karena tanpa adanya dasar atau SOP dalam melaksanakan tugas, maka pekerjaan tidak akan memenuhi standar yang disahkan oleh pemerintah. Beliau juga menjelaskan, bahwasanya Kota Yogyakarta yang mempunyai hukum adat turun-temurun menjadikan modal bagi para karyawan pada saat bekerja dan didampingi oleh SOP yang diberlakukan disetiap departemen, sehingga dapat meminimalisir kesalahan.

\section{Tantangan yang dihadapi departemen $F \& B$ pada masa pandemi Covid-19.}

Tahun 2020 adalah tahun dimana Virus Corona (Covid-19) mulai menyebar di Indonesia, beratus-ratus kalangan masyarakat yang terjangkit setiap harinya, diadakannya lockdown diberbagai wilayah di Indonesia, karantina mandiri bagi keluarga yang datang dari luar kota, masyarakat wajib menggunakan masker dan tidak lupa membawa hand sanitizer, tempat-tempat seperti pasar, swalayan, mall dan sekolah, perusahaan wajib mempunyai tempat cuci tangan. Hal ini guna mencegah penyebaran virus dan juga memperlambat penularan ke masyarakat luas.

Pandemi Covid-19 ini berakibat pula pada sektor pariwisata, pendidikan, sosial, ekonomi dan politik. Dimana ketegangan berada dimana-mana dan juga ketakutan masyarakat yang semakin menjadi-jadi. Terkhusus pada sektor pariwisata, yang menutup semua akses berkunjung karena ditakutkan mengundang keramaian dan berdampak pula pada bisnis perhotelan yang semakin lama semakin menurun, sehingga berakibat pada pemberlakuan Pemutusan Hubungan Kerja (PHK). Hal ini sangat-sangat membuat rugi banyak pihak karena di tengah-tengah pandemi ini masyarakat dihadapkan dengan dua kemungkinan yaitu mati karena virus Covid-19 atau mati karena kelaparan, sebab masyarakat yang berpendapatan dibawah, tidak 
4135 Implementasi Nilai-Nilai Pancasila dalam Food And Beverage Departemen di Restoran Hotel New Saphir Yogyakarta - Heri Kurnia, Ida Ayu Sriyogani, Nuryati

DOI: https://doi.org/10.31004/basicedu.v5i5.1473

dapat memenuhi kebutuhan hidup apa lagi dengan adanya PHK yang semakin membuat masyarakat khawatir akan keadaan ini.

Covid-19 juga dirasakan di Daerah Istimewa Yogyakarta, yang sempat beberapa kali mengadakan lockdown atau PSBB di beberapa wilayah zona merah, yang berimbas pula pada banyak hal termasuk menurunya jumlah tamu baik di perhotelan, taman wisata dan pusat perbelanjaan. Begitu juga di Hotel New Saphir Yogyakarta, yang dimana pihak hotel mengadakan pengurangan karyawan, sebab dikhawatirkan akan berimbas pada jalannya operasional Hotel. Bapak Isma selaku Staff Maintenance and Technic Hotel Saphir Bersama 3 staff $F$ dan $B$ mengatakan bahwa:

"Covid-19 ini sangat merugikan masyarakat luas, sebab adanya virus ini masyarakat menjadi terbatas aktivitasnya dan juga pemasukan untuk bertahan hidup pun juga berkurang, hal ini juga yang mengakibatkan jumlah kejahatan meningkat banyak pihak yang mencari uang dengan cara merampok, mencuri dan lain-lain". (Yogyakarta, 25 Mei 2021).

\section{KESIMPULAN}

Implementasi nilai-nilai Pancasila dalam kehidupan sehari-hari sudah sering kita dengar bahkan kita terapkan, mulai dari sila pertama sampai sila kelima ada disetiap aktifitas masyarakat. Jika di lingkungan masyarakat berupa nilai-nilai Pancasila, maka di ranah perusahaan dapat disebut sebagai SOP (standar operasional prosedure). SOP ini, dibuat berdasarkan nilai-nilai Pancasila dimana SOP lebih memudahkan karyawan Hotel untuk menerapkannya pada saat bekerja.

Hasil wawancara dengan karyawan Hotel, bahwasanya di sana telah melaksanakan nilai-nilai Pancasila mulai dari sila pertama hingga sila kelima. Sila pertama, yang berhubungan dengan makanan halal dan non halal, karyawan yang beribadah sesuai dengan kepercayaan masing-masing. Sila kedua, dalam memproduksi dan memberikan pelayanan pada customer departemen $F \& B$ selalu mengikuti SOP yang telah ditetapkan oleh Hotel, tidak membedakan antara customer satu dengan yang lain, namun memperhatikan permintaan customer. Sila ketiga, menghargai sesama karyawan baik dalam lingkungan $F \& B$ termasuk manajemen diluar $F \& B$ adalah suatu keharusan, kerjasama dalam satu tim yang kuat merupakan keharusan, karena dengan kerja tim yang baik akan dihasilkan produk dan pelayanan yang baik pula. Sila keempat, sebelum melaksanakan tugas, selalu diadakan briefing sehingga diharapkan akan dapat bekerja nyaman dan jika ada permasalahan dalam pelaksanaan tugas produk maupun pelayanan diselesaikan dengan cara musyawarah untuk mufakat, akan terjadi saling memperkuat antar tim satu dengan yang lain. Sila kelima, kebersamaan dan keadilan bersama merupakan tujuan bersama, bagi yang terlemah akan mendapat perhatian khusus, yang kuat dengan kesadaran penuh pasti membantu yang lemah, misalnya bagian produk mengalami kesulitan, maka bagian yang kuat akan membantu.

\section{DAFTAR PUSTAKA}

Ahmad, H., \& Sigarete, B. G. (2018). Preferensi Mahasiswa Dalam Berwisata: Studi Kasus Mahasiswa Sekolah Tinggi Pariwisata Ambarrukmo (STIPRAM), Yogyakarta. Jurnal Kepariwisataan. Http://Ejournal.Stipram.Ac.Id/Index.Php/Kepariwisataan/Article/Download/95/77

Antari, L. P. S., \& Liska, L. De. (2020). Implementasi Nilai Nilai Pancasila Dalam Penguatan Karakter Bangsa. Widyadari: Jurnal Pendidikan. Https://Ojs.Mahadewa.Ac.Id/Index.Php/Widyadari/Article/View/916

Arliman, L. (2018). Peran Investasi Dalam Kebijakan Pembangunan Ekonomi Bidang Pariwisata Di Provinsi Sumatera Barat. Kanun Jurnal Ilmu Hukum. Http://ERepository.Unsyiah.Ac.Id/Kanun/Article/View/10081 
4136 Implementasi Nilai-Nilai Pancasila dalam Food And Beverage Departemen di Restoran Hotel New Saphir Yogyakarta - Heri Kurnia, Ida Ayu Sriyogani, Nuryati

DOI: https://doi.org/10.31004/basicedu.v5i5.1473

Asmaroini, A. P. (2016). Implementasi Nilai-Nilai Pancasila Bagi Siswa Di Era Globalisasi. Citizenship Jurnal Pancasila Dan .... Http://E-Journal.Unipma.Ac.Id/Index.Php/Citizenship/Article/View/1077

Damanhuri, D., Bahrudin, F. A., Legiani, W. H., \& ... (2016). Implementasi Nilai-Nilai Pancasila Sebagai Upaya Pembangunan Karakter Bangsa. Untirta Civic Http://Jurnal.Untirta.Ac.Id/Index.Php/UCEJ/Article/View/1890

Hanief, S., Pramana, D., Kom, S., \& Kom, M. (2018). Pengembangan Bisnis Pariwisata Dengan Media Sistem Informasi. Books.Google.Com. Https://Books.Google.Com/Books?Hl=En\%5C\&Lr=\%5C\&Id=Xbzndwaaqbaj\%5C\&Oi=Fnd\%5C\&Pg= PA44\%5C\&Dq=Pariwisata\%5C\&Ots=Mvepca6gjx\%5C\&Sig=Cqgibl1rjn46en6f_D4scvjzs8w

Hidayah, N. (2019). Pemasaran Destinasi Pariwisata. Senayan.Iain-Palangkaraya.Ac.Id. Http://Senayan.IainPalangkaraya.Ac.Id/Index.Php?P=Show_Detail\%5C\&Id=13991

Holidah, N. (N.D.). Bahasa Inggris Sebagai Faktor Penunjang Dalam Operasional Food And Beverage Di Hotel Bandung Permai. Repository.Unej.Ac.Id. Https://Repository.Unej.Ac.Id/Handle/123456789/82716

Hutahean, Y. (2016). Tata Cara Pengelolaan Penyimpanan Bahan Baku Di Hotel New Saphir Yogyakarta. Repositori.Usu.Ac.Id. Http://Repositori.Usu.Ac.Id/Handle/123456789/20136

Kepariwisataan, U. R. N. 10. T. 2009. (2009). Undang-Undang Republik Indonesia Nomor 10.Tahun 2009 Tentang Kepariwisataan. 57, 3.

Kurniawan, A., \& Sidiq, S. S. (2016). Penerapan Personal Hygiene Pada Karyawan Food And Beverage Service Hotel Aryaduta Pekanbaru. Https://Www.Neliti.Com/Publications/126890/Penerapan-Personal-Hygiene-Pada-Karyawan-Food-AndBeverage-Service-Hotel-Aryadut

Lexi, J. M. (2001). Qualitative Research Methodology, PT. Remaja Rosdakarya, Bandung.

Lexi, J. M. (2005). Metode Penelitian Kualitatif, Ed. Revisi. Bandung: PT. Remaja Rosdakarya.

Moleong, L. J. (2002). Penelitian Metodelogi Kualitatif. Bandung: Remaja Rosdakarya.

Moleong, L. J. (2009). Metodologi Penelitian Kumulatif. Bandung: PT Remaja Rosdakarya.

Moleong, L. J. (2010). Methodology Of Qualitative Research. Bandung: Remaja Rosda Karya.

N. R. Harsono Dan F. Yusrizal. (2013). Motivasi Wisatawan Mengunjungi Objek Wisata Di Desa Pawan Kabupaten Rokan Hulu. Journal Of Chemical Information And Modeling, 53(9), 1689-1699.

Nasrullah, N., Susanty, S., Rusli, M., Sudarso, A., Purba, P. B., \& ... (2020). Pemasaran Pariwisata: Konsep, Perencanaan I\& Implementasi. Books.Google.Com. Https://Books.Google.Com/Books?Hl=En\%5C\&Lr=\%5C \&Id=Apgceaaaqbaj\%5C \&Oi=Fnd\%5C\&Pg=P A1\%5C\&Dq=Pariwisata\%5C\&Ots=O18135m9ue\%5C\&Sig=_Aq_Nolrvvysxzvjwnjd-7_Gs0o

Nuralam, K., \& Sulistyani, A. (2017). Koordinasi Kerja Food And Beverage Service Dengan Food And Beverage Product Dalam Operasional Breakfast Di Hotel Aston Tanjungpinang. Neliti.Com. Https://Www.Neliti.Com/Publications/206371/Koordinasi-Kerja-Food-And-Beverage-Service-DenganFood-And-Beverage-Product-Dala

Pradana, G. Y. K. (2019). Sosiologi Pariwisata. Stpbi Press. Https://Www.Academia.Edu/Download/63096028/DIKTAT_SOSIOLOGI_PARIWISATA2020042662899-Cf813n.Pdf

PUTRANTO, R. W. (2017). Proses Penerimaan Serta Pembelian Barang Untuk Food And Beverage Departemen Di Holiday Inn Express Surabaya Center Plaza. Repository.Unair.Ac.Id. Http://Repository.Unair.Ac.Id/70625/

Revida, E., Gaspersz, S., Uktolseja, L. J., Nasrullah, N., \& ... (2020). Pengantar Pariwisata. Books.Google.Com.

Https://Books.Google.Com/Books?Hl=En\%5C\&Lr=\%5C\&Id=Eeb8dwaaqbaj\%5C\&Oi=Fnd\%5C\&Pg=P 
4137 Implementasi Nilai-Nilai Pancasila dalam Food And Beverage Departemen di Restoran Hotel New Saphir Yogyakarta - Heri Kurnia, Ida Ayu Sriyogani, Nuryati

DOI: https://doi.org/10.31004/basicedu.v5i5.1473

A1\%5C \&Dq=Pariwisata\%5C \&Ots=1Mag0pmo8a\%5C \&Sig=Nxrgxqskymclvvdhecefe0uvaxs

Ridwan, M., \& Aini, W. (2019). Perencanaan Pengembangan Daerah Tujuan Pariwisata. Books.Google.Com.

Https://Books.Google.Com/Books?Hl=En\%5C\&Lr=\%5C\&Id=Zaffdwaaqbaj\%5C\&Oi=Fnd\%5C\&Pg=P R5\%5C\&Dq=Pariwisata\%5C\&Ots=Gi8ejcwcjj\%5C\&Sig=X4svqlczu_Buiuolu7zpzpdzhgq

Rusyidi, B., \& Fedryansah, M. (2018). Pengembangan Pariwisata Berbasis Masyarakat. Focus: Jurnal Pekerjaan Sosial. Http://Jurnal.Unpad.Ac.Id/Focus/Article/View/20490

Sasaka, A. L. (2019). Upaya Pelayanan Banquet Food And Beverage Department Untuk Meningkatkan Event Di Ballroom Verwood Hotel And Serviced Residence. Repository.Unair.Ac.Id. Http://Repository.Unair.Ac.Id/87491/

SUGIARNO, S. (2017). Pemenuhan Standar Kualitas Makanan Pada Departemen Food $\backslash \&$ Beverage Product Di Hotel Natya Gili Trawagan. Eprints.Unram.Ac.Id. Http://Eprints.Unram.Ac.Id/3940/

Sugiyono. (2014). Prof. Dr. Sugiyono, Metode Penelitian Pendidikan, Pendekatan Kuantitatif. Intro ( Pdfdrive ).Pdf.

Wulansari, D. M., \& Hakim, F. N. (2019). Pelaksanaan Operasional Food And Beverage Department Dalam Pencapian Excelent Service Di Crystal Lotus Hotel Yogyakarta. Khasanah Ilmu-Jurnal Pariwisata Dan .... Https://Ejournal.Bsi.Ac.Id/Ejurnal/Index.Php/Khasanah/Article/View/6681

Yuningsih, T., Darmi, T., \& Sulandari, S. (2019). Model Pentahelik Dalam Pengembangan Pariwisata Di Kota Semarang. JPSI (Journal Of Public. Https://Journal.Unesa.Ac.Id/Index.Php/Jpsi/Article/View/4851

Yusnita, H., \& Yulianto, A. (2013). Upaya Food And Beverage Restaurant Dalam Meningkatkan Kepuasan Tamu Melalui Variasi Produk. Jurnal Khasanah Ilmu, IV(1), 67-81. 